UDC 339.72.053

DOI: https://doi.org/10.32782/2304-0920/4-83-3

\author{
Yakubovskiy Sergey \\ Lomachynska Iryna \\ Ivaniv-Dubna Maryna \\ Odessa I. I. Mechnikov National University
}

\title{
IMPACT OF FOREIGN INVESTMENT INCOME ON PUBLIC AND EXTERNAL DEBT OF THE NORDIC COUNTRIES
}

The study is devoted to the analysis of the dynamics, structure and special characteristics of the public debt of Northern Europe and the impact of investment income on public and external debt of Norway, Denmark, Finland, Sweden. Empirical analysis based allowed to assess the relationship between income from foreign investment and the level of public and external debt of these countries. According to the results of the analysis revealed that income from direct, portfolio and other investments affect debt and vice versa. Incomes from portfolio investments received by Norway, affects its external debt. There is an interdependence between the external debt and the income from other investments of Norway. In Denmark, external debt affects the return on direct and other investments. In Finland, a change in income from other investments entails a change in the level of external debt. In Sweden, portfolio investment income affects external debt and vice versa. In turn, Sweden's external debt affects the income of other investments. Thus, it is proved that investment income is one of the main factors influencing the dynamics of public and external debt of Northern Europe.

Keywords: investment income, public debt, external debt, Nordic countries.

Introduction. Each country in the world has its own financial system, which is a reflection of the forms and methods of specific use of finance in the economy. One of the necessary conditions for the effective development of the economy is the formation of a clear mechanism of monetary regulation, which allows the central bank to influence financial activity, control the activities of commercial banks. Another important factor in the successful development of the economy of any country is the effective and competent management of public finances, which is expressed in the conduct of public financial policy.

The analysis of the main financial indicators allows to assess the general state of the economy, to determine the prospects for further development of the country, to analyze opportunities for attracting foreign capital, to reveal factors that directly determine the functioning of the economy, both shortterm and long-term. They also serve as a basis for defining public policy and making social, economic and political decisions.

Recent literature review. International investments are important for any state, and their impact on economic development is not always positive. That is why the influence of foreign capital on host countries is widely studied in the literature $[1 ; 2 ; 3]$.

For most research countries, portfolio and other income have impact on the accumulation of exter- 
nal debt. This applies to Argentina, Brazil, Hungary, Bulgaria and Ukraine. In Hungary, there is mutual causality for all the variables in question. In the Czech Republic, Hungary, Bulgaria and Poland, the level of external debt causes income flows. FDI income flows are significant for accumulation of debt in Brazil, Hungary and Ukraine [4].

Alstadheim i Blandhol [5] examined a model based on financial cycles. The authors found that when global activity falls, the share of foreign bank financing falls. The results suggest that global real activity, rather than the global financial cycle, is a major factor in bank capital inflows. Monetary policy affects activity and inflation in a standard way, and the exchange rate acts as a buffer when shocks affect the economy [5].

The purpose of research is to conduct an economic analysis of the impact of foreign investment income on the external economic position of the Nordic countries. The article is a continuation of the research by the authors of the financial aspects of the development of the economies of the Nordic countries [6].

The main results of the research. Public debt of Norway in the first quarter of 2020 is 1,469 billion Norwegian krone, which in relation to GDP $41.4 \%$. In the period 2006-2009, the debt decreased, in 2009 it amounted to $42.8 \%$ of GDP. The minimum value of public debt was recorded in 2015$33.4 \%$. Central government debt began to increase in 2016, and this trend continues to this day. In 2019 , it was $40.4 \%$. That is, in monetary terms, the debt increased by 172 billion Norwegian krone, and in relation to GDP increased by $4.8 \%$ [7]. In 2019, the main financial instruments of public debt are loans of $60 \%$, debt securities $-40 \%$. At the end of 2019 , the share of debt held by resident financial corporations was $49 \%$ [8]. Resident non-financial sectors (non-financial corporations, households) held only $4 \%$ of debt, non-residents (the rest of the world sector) $-47 \%$ [9].

Denmark's public debt in 2006 amounted to 530.74 billion Danish krone or $31.5 \%$ of GDP. In 2007, the debt decreased by 55.24 billion Danish krone. But from 2008 to 2011, public debt increased. The maximum public debt was in $2011-46.1 \%$ of GDP. In the following years, there was a decline until 2013. In 2014, public debt increased again by $0.3 \%$. In the period 2015-2019, public debt decreased, and in 2019 amounted to $33.3 \%$ of GDP [5] (Figure 1). In 2019, the main financial instruments of public debt are currency and deposits $-3 \%$, debt securi- ties $-75 \%$, loans $-22 \%$ [8]. At the end of 2019, the share of debt held by resident financial corporations was $73.7 \%$, resident non-financial sectors (non-financial corporations, households) held only $2.3 \%$ of debt, non-residents (the rest of the world sector) $24 \%$ [9].

Sweden's public debt in 2006 was $1,269.95$ billion Swedish krone or $43.9 \%$ of GDP. By 2008 , the debt was declining and amounted to 1036.22 billion Swedish krone. In 2009, public debt to GDP increased by $3.2 \%$. Although public debt decreased to $38.1 \%$ of GDP in 2010, in 2012, during the second wave of the recession, it began to grow again. In 2015, the public debt was the maximum and amounted to $1,403.42$ billion Swedish krone. In 2019, this figure is equal to 1,112 billion Swedish krone or $35.2 \%$ of GDP, i.e. is the minimum for the study period [7].

Finland's public debt to GDP in 2006 was 65.89 billion EUR or $38.1 \%$ of GDP. By 2008, public debt was declining to 63.25 billion EUR. In 2012, the debt amounted to 107.8 billion EUR $(53.6 \%$ of GDP). In 2015, public debt amounted to 134.52 billion EUR ( $63.6 \%$ of GDP). One of the main reasons for the growth of public debt is weak economic growth in the country. The second important reason for the growth of debt is the demographic aging of the country's population. In the period 2016-2019, public debt increased, and in 2019 amounted to 142.48 billion EUR [7]. In 2019, the main financial instruments of public debt in Finland are currency and deposits $-1 \%$, debt securities $-75 \%$, loans $24 \%$ [8].

Borrowed resources play an important role for any state. The study of the impact of various types of investments on the external debt of countries has not received due attention. In research, important attention must be paid to the type of investment. Since, each type of investment has different focus. Direct investments are aimed at acquiring control over the placement object, portfolio investments at making profit, without the right to control, others - all those investments that are not included in the first two positions.

In order to test the hypothesis that external debt can be a factor causing economic imbalances in the countries of Northern Europe, a vector auto-regression model (VAR) was constructed, the advantage of which is a systematic approach to cover the dynamics of many time series. Thus, to identify the mutual causality between external debt (total value of external direct debt instruments, debt securities of portfolio investments, other debt instruments of investments)

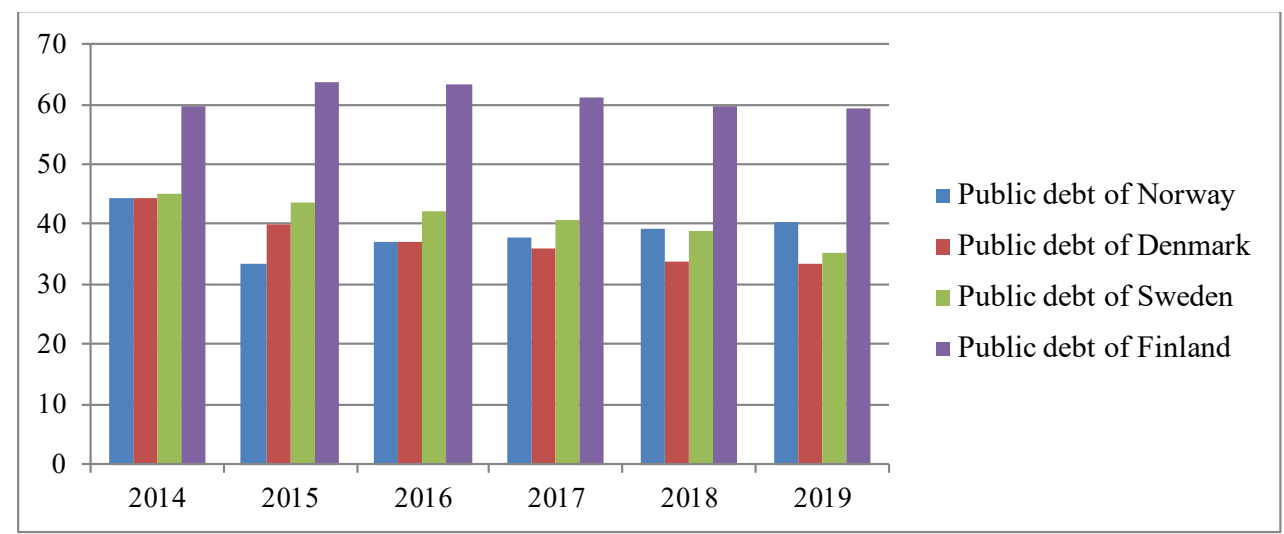

Source: [7]

Figure 1. Dynamics of public debt to GDP, \% 
and incomes of direct, portfolio, other investments of Norway, Denmark, Finland, Sweden, in the structure of the next VAR is estimated Granger test:

$$
\begin{aligned}
& \mathrm{ED}_{\mathrm{t}}=\alpha_{1}+\sum_{\mathrm{i}=1}^{\mathrm{p}} \beta_{1 \mathrm{i}} \text { Inc }_{\mathrm{t}-\mathrm{i}}+\sum_{\mathrm{i}=1}^{\mathrm{p}} \gamma_{1 \mathrm{i}} \mathrm{ED}_{\mathrm{t}-\mathrm{i}}+\varepsilon_{1 \mathrm{t}} \\
& \text { Inc }_{\mathrm{t}}=\alpha_{2}+\sum_{\mathrm{i}=1}^{\mathrm{p}} \beta_{2 \mathrm{i}} \mathrm{ED}_{\mathrm{t}-\mathrm{i}}+\sum_{\mathrm{i}=1}^{\mathrm{p}} \gamma_{2 \mathrm{i}} \text { Inc }_{\mathrm{t}-\mathrm{i}}+\varepsilon_{2 \mathrm{t}}
\end{aligned}
$$

Where $\mathrm{ED}, \mathrm{PD}$ is the external and public debt, Inc is the income for each type of investment (direct, portfolio, others) and the error term; $\alpha$ is constant term; $\beta$ and $\gamma$ denote the coefficients to be estimated, $\mathrm{p}$ is the selected order of lag. The null hypothesis of Granger's causality from Inc to ED and from ED to Inc are $\beta_{1 \mathrm{i}}=0$ and $\beta_{2 \mathrm{i}}=0$, respectively.

Yearly data are used, information on external and public debt are received from the statistics of the World Bank and European central bank [10;11] and balance of payments from the database of the International Monetary Fund [12].

The Granger causality test provides an opportunity for a more reliable analysis of the impact of capital inflows on the development of the economies of the research countries. Identification of the relationship between income from direct, portfolio, other investments (assets) and the growth of external debt of Norway, Denmark, Finland and Sweden are presented in table 1 . In the context of separate countries, results are different.

According to the Granger causality test for Norway: portfolio investment returns affect external debt. And between external debt and income from other investments there is a mutual dependence. In Denmark, investment income does not affect the growth of external debt. At the same time, external debt affects the income from direct and other investments.
According to the Granger causality test for Norway: portfolio investment returns affect external debt. And between external debt and income from other investments there is a mutual dependence. In Denmark, investment income does not affect the growth of external debt. At the same time, external debt affects the income from direct and other investments.

For Finland, a change in the income from other investments entails a change in the level of external debt. In Sweden, direct investment income and external debt are independent of each other. Portfolio investment income affects external debt and vice versa. External debt affects the return on other investments.

Identification of the relationship between income from direct, portfolio, other investments (liabilities) and the growth of external debt of Norway, Denmark, Finland, Sweden are presented in table 2. In the context of separate countries, results are different.

From the Granger causality test conducted for Norway, it follows that income from direct investments attracted to the country affects external debt. At the same time, there is mutual causality between portfolio, other investment income and external debt. For Denmark: direct and portfolio investment returns affect external debt. External debt only affects income from other investments. In Finland: there is no correlation between direct investment income and external debt. And income from other investments affects debt. The influence of external debt on the return on portfolio investments was also identified. In Sweden, there is a mutual causality between external debt and portfolio and other investment income.

Granger causality test for external debt growth and all types of investment (assets) income flows

\begin{tabular}{|c|c|c|c|c|c|}
\hline \multirow{2}{*}{ Country } & \multirow{2}{*}{ Indicators } & \multicolumn{4}{|c|}{ Lags } \\
\hline & & External debt & FDI income & Portfol. income & Other income \\
\hline \multirow{4}{*}{$\begin{array}{c}\text { Norway } \\
(1998-2018)\end{array}$} & External debt & & $\begin{array}{ll}2.40 \\
(0.49) \\
\end{array}$ & $\begin{array}{ll}1.05 \\
(0.78) \\
\end{array}$ & $\begin{array}{l}173.09 \\
(0.00)^{\mathrm{a}}\end{array}$ \\
\hline & FDI income & $\begin{array}{c}0.47 \\
(0.92) \\
\end{array}$ & & & \\
\hline & Portfol. income & $\begin{array}{l}25.37 \\
(0.00)^{\mathrm{a}} \\
\end{array}$ & & & \\
\hline & Other income & $\begin{array}{l}7.27 \\
(0.06)^{\mathrm{c}} \\
\end{array}$ & & & \\
\hline \multirow{4}{*}{$\begin{array}{c}\text { Denmark } \\
(1998-2019)\end{array}$} & External debt & & $\begin{array}{l}21.17 \\
(0.00)^{\mathrm{a}}\end{array}$ & $\begin{array}{c}6.61 \\
(0.25) \\
\end{array}$ & $\begin{array}{l}96.84 \\
(0.00)^{\mathrm{a}}\end{array}$ \\
\hline & FDI income & $\begin{array}{c}6.09 \\
(0.29)\end{array}$ & & & \\
\hline & Portfol. income & $\begin{array}{l}1.01 \\
(0.96) \\
\end{array}$ & & & \\
\hline & Other income & $\begin{array}{c}0.78 \\
(0.85) \\
\end{array}$ & & & \\
\hline \multirow{4}{*}{$\begin{array}{c}\text { Finland } \\
(1998-2019)\end{array}$} & External debt & & $\begin{array}{c}5.78 \\
(0.12)\end{array}$ & $\begin{array}{c}2.6 \\
(0.10)\end{array}$ & $\begin{array}{l}1.16 \\
(0.76)\end{array}$ \\
\hline & FDI income & $\begin{array}{l}1.34 \\
(0.71) \\
\end{array}$ & & & \\
\hline & Portfol. income & $\begin{array}{l}0.13 \\
(0.71) \\
\end{array}$ & & & \\
\hline & Other income & $\begin{array}{r}8.20 \\
(0.04)^{b} \\
\end{array}$ & & & \\
\hline \multirow{4}{*}{$\begin{array}{c}\text { Sweden } \\
(1998-2019)\end{array}$} & External debt & & $\begin{array}{c}2.67 \\
(0.10) \\
\end{array}$ & $\begin{array}{l}36.17 \\
(0.00)^{\mathrm{a}}\end{array}$ & $\begin{array}{c}71.98 \\
(0.00)^{\mathrm{a}}\end{array}$ \\
\hline & FDI income & $\begin{array}{l}0.009 \\
(0.92)\end{array}$ & & & \\
\hline & Portfol. income & $\begin{array}{c}8.92 \\
(0.03)^{\mathrm{b}}\end{array}$ & & & \\
\hline & Other income & $\begin{array}{l}5.19 \\
(0.15)\end{array}$ & & & \\
\hline
\end{tabular}

Table 1

Note: ED denotes external debt growth. Behind the country name the sample range is listed in parentheses. The numbers in the parentheses beside the Wald statistics are the P-values: a, b, c represent the $1 \%, 5 \%$, and $10 \%$ significance levels, respectively. Source: calculated by the authors 
Table 2

Granger causality test for external debt growth and all types of investment (liabilities) income flows

\begin{tabular}{|c|c|c|c|c|c|}
\hline \multirow{2}{*}{ Country } & \multirow{2}{*}{ Indicators } & \multicolumn{4}{|c|}{ Lags } \\
\hline & & External debt & FDI income & Portfol. income & Other income \\
\hline \multirow{4}{*}{$\begin{array}{c}\text { Norway } \\
(1998-2018)\end{array}$} & External debt & & $\begin{array}{l}1.61 \\
(0.65) \\
\end{array}$ & $\begin{array}{l}80.74 \\
\left(0.00^{\mathrm{a}}\right) \\
\end{array}$ & $\begin{array}{c}25.4 \\
\left(0.00^{\mathrm{a}}\right) \\
\end{array}$ \\
\hline & FDI income & $\begin{array}{r}6,94 \\
(0.07)^{c}\end{array}$ & & & \\
\hline & Portfol. income & $\begin{array}{l}122.49 \\
(0.00)^{\mathrm{a}}\end{array}$ & & & \\
\hline & Other income & $\begin{array}{l}17.64 \\
(0.00)^{\mathrm{a}}\end{array}$ & & & \\
\hline \multirow{4}{*}{$\begin{array}{c}\text { Denmark } \\
(1998-2019)\end{array}$} & External debt & & $\begin{array}{c}4.33 \\
(0.22) \\
\end{array}$ & $\begin{array}{c}0.1 \\
(0.75)\end{array}$ & $\begin{array}{l}77.32 \\
\left(0.00^{\mathrm{a}}\right)\end{array}$ \\
\hline & FDI income & $\begin{array}{r}86.82 \\
\left(0.00^{\mathrm{a}}\right) \\
\end{array}$ & & & \\
\hline & Portfol. income & $\begin{array}{r}9.80 \\
\left(0.00^{a}\right) \\
\end{array}$ & & & \\
\hline & Other income & $\begin{array}{l}0.77 \\
(0.85) \\
\end{array}$ & & & \\
\hline \multirow{4}{*}{$\begin{array}{c}\text { Finland } \\
(1998-2019)\end{array}$} & External debt & & $\begin{array}{c}0.12 \\
(0.93) \\
\end{array}$ & $\begin{array}{r}34.99 \\
\left(0.00^{\mathrm{a}}\right) \\
\end{array}$ & $\begin{array}{l}1.69 \\
(0.63) \\
\end{array}$ \\
\hline & FDI income & $\begin{array}{l}0.05 \\
(0.97) \\
\end{array}$ & & & \\
\hline & Portfol. income & $\begin{array}{l}4.45 \\
(0.21) \\
\end{array}$ & & & \\
\hline & Other income & $\begin{array}{l}56.21 \\
\left(0.00^{a}\right) \\
\end{array}$ & & & \\
\hline \multirow{4}{*}{$\begin{array}{c}\text { Sweden } \\
(1998-2019)\end{array}$} & External debt & & $\begin{array}{l}2.09 \\
(0.55) \\
\end{array}$ & $\begin{array}{l}16.22 \\
\left(0.00^{\mathrm{a}}\right) \\
\end{array}$ & $\begin{array}{c}7.12 \\
\left(0.06^{\mathrm{c}}\right) \\
\end{array}$ \\
\hline & FDI income & $\begin{array}{l}1.47 \\
(0.68)\end{array}$ & & & \\
\hline & Portfol. income & $\begin{array}{l}10.93 \\
\left(0.01^{a}\right)\end{array}$ & & & \\
\hline & Other income & $\begin{array}{c}9.28 \\
\left(0.02^{\mathrm{b}}\right) \\
\end{array}$ & & & \\
\hline
\end{tabular}

Note: ED denotes external debt growth. Behind the country name the sample range is listed in parentheses. The numbers in the parentheses beside the Wald statistics are the P-values: a, b, c represent the $1 \%, 5 \%$, and $10 \%$ significance levels, respectively. Source: calculated by the authors

According to the Granger causality test for Norway: direct and portfolio investment returns affect the increase in public debt; and an increase in external debt, in turn, leads to an increase in other income flows. For Denmark, there is a mutual causality between the level of public debt and the income of other investments, and the accumulation of public debt affects the growth of portfolio and other investment income. For Finland, a change in the public debt indicator entails a change in the income levels of direct and portfolio investments. For Sweden, no mutual causality was found between the research variables. The level of public debt and all investment flows are independent of each other.

Identification of the relationship between income from direct, portfolio, other investments (liabilities) and the growth of public debt of Norway, Denmark, Finland, Sweden are presented in table 4 . In the context of separate countries, results are different.

From the Granger causality test conducted for Norway, it follows that the direct investment income that was attracted to the country affects public debt. At the same time, the influence of public debt on direct investment income was not revealed. There is a mutual causality between portfolio investment returns and public debt growth. Income from other investments and public debt do not affect each other. For Denmark: there is a mutual dependence between direct investment income and debt. Income from portfolio and other investments affect the value of public debt. For Finland: there is no correlation between direct investment income and public debt. And income from portfolio and other investments affect the public debt. For Sweden: the impact of debt on portfolio investment income was identified.

Conclusions. Public debt is the largest in Sweden and the smallest in Denmark. In relation to GDP, the largest debt is observed in Finland $-59.2 \%$ of GDP. In Denmark, public debt is $33.3 \%$ of GDP, in Sweden $-35.2 \%$ of GDP, Norway $-40.4 \%$. That is, the public debt of these countries is moderate, and in comparison with other countries is quite low. A necessary condition for further acceleration of economic development is to increase productivity in the country, which requires improved conditions for competition, attracting highly qualified personnel, as well as further development of innovation.

Granger's causality test for increasing external debt and direct, portfolio and other investment income showed that portfolio investment income, received by Norway affect external debt. And between external debt and income from other investments there is a mutual dependence. In Denmark external debt affects the income from direct and other investments. For Finland, a change in the income from other investments entails a change in the level of external debt. In Sweden, portfolio investment income affects external debt and vice versa. External debt affects the return on other investments.

Granger causality test conducted to identify the dependence between investment income, which was paid by Norway and external debt showed: that income from direct investments affects external debt. At the same time, there is mutual causality between portfolio, other investment income 
Table 3

Granger causality test for public debt growth and all types of investment (assets) income flows

\begin{tabular}{|c|c|c|c|c|c|}
\hline \multirow{2}{*}{ Country } & \multirow{2}{*}{ Indicators } & \multicolumn{4}{|c|}{ Lags } \\
\hline & & Public debt & FDI income & Portfol. income & Other income \\
\hline \multirow{4}{*}{$\begin{array}{l}\text { Norway } \\
(1998-2018)\end{array}$} & Public debt & & $\begin{array}{c}4.92 \\
(0.42)\end{array}$ & $\begin{array}{c}4.9 \\
(0.43)\end{array}$ & $\begin{array}{l}19.26 \\
(0.00)^{a}\end{array}$ \\
\hline & FDI income & $\begin{array}{l}11.91 \\
(0.03)^{\mathrm{b}}\end{array}$ & & & \\
\hline & Portfol. income & $\begin{array}{c}9.75 \\
(0.08)^{\mathrm{c}}\end{array}$ & & & \\
\hline & Other income & $\begin{array}{c}2.43 \\
(0.78) \\
\end{array}$ & & & \\
\hline \multirow{4}{*}{$\begin{array}{c}\text { Denmark } \\
(1998-2019)\end{array}$} & Public debt & & $\begin{array}{c}0.55 \\
(0.76)\end{array}$ & $\begin{array}{l}45.91 \\
(0.00)^{\mathrm{a}}\end{array}$ & $\begin{array}{l}22.42 \\
(0.00)^{\mathrm{a}}\end{array}$ \\
\hline & FDI income & $\begin{array}{c}0.39 \\
(0.82)\end{array}$ & & & \\
\hline & Portfol. income & $\begin{array}{c}6.59 \\
(0.25) \\
\end{array}$ & & & \\
\hline & Other income & $\begin{array}{l}20.46 \\
(0.00)^{\mathrm{a}}\end{array}$ & & & \\
\hline \multirow{4}{*}{$\begin{array}{c}\text { Finland } \\
(1998-2019)\end{array}$} & Public debt & & $\begin{array}{l}17.45 \\
(0.00)^{\mathrm{a}}\end{array}$ & $\begin{array}{l}12.47 \\
(0.02)^{\mathrm{b}}\end{array}$ & $\begin{array}{l}1.74 \\
(0.18) \\
\end{array}$ \\
\hline & FDI income & $\begin{array}{l}7.84 \\
(0.16) \\
\end{array}$ & & & \\
\hline & Portfol. income & $\begin{array}{c}4.98 \\
(0.42)\end{array}$ & & & \\
\hline & Other income & $\begin{array}{c}0.37 \\
(0.54)\end{array}$ & & & \\
\hline \multirow{4}{*}{$\begin{array}{c}\text { Sweden } \\
(1998-2019)\end{array}$} & Public debt & & $\begin{array}{l}1.07 \\
(0.29)\end{array}$ & $\begin{array}{c}2.18 \\
(0.33)\end{array}$ & $\begin{array}{l}1.34 \\
(0.51)\end{array}$ \\
\hline & FDI income & $\begin{array}{l}0.57 \\
(0.45) \\
\end{array}$ & & & \\
\hline & Portfol. income & $\begin{array}{l}1.44 \\
(0.48) \\
\end{array}$ & & & \\
\hline & Other income & $\begin{array}{c}0.93 \\
(0.62)\end{array}$ & & & \\
\hline
\end{tabular}

Note: ED denotes public debt growth. Behind the country name the sample range is listed in parentheses. The numbers in the parentheses beside the Wald statistics are the P-values: $a, b$, c represent the $1 \%, 5 \%$, and $10 \%$ significance levels, respectively. Source: calculated by the authors

Table 4

Granger causality test for public debt growth and all types of investment (liabilities) income flows

\begin{tabular}{|c|c|c|c|c|c|}
\hline \multirow{2}{*}{ Country } & \multirow{2}{*}{ Indicators } & \multicolumn{4}{|c|}{ Lags } \\
\hline & & Public debt & FDI income & Portfol. income & Other income \\
\hline \multirow{4}{*}{$\begin{array}{c}\text { Norway } \\
(1998-2018)\end{array}$} & Public debt & & $\begin{array}{c}9.13 \\
(0.10) \\
\end{array}$ & $\begin{array}{c}7.28 \\
\left(0.00^{a}\right)\end{array}$ & $\begin{array}{c}6.83 \\
(0.23) \\
\end{array}$ \\
\hline & FDI income & $\begin{array}{c}9.72 \\
(0.08)^{\mathrm{c}} \\
\end{array}$ & & & \\
\hline & Portfol. income & $\begin{array}{c}2.78 \\
(0.09)^{\mathrm{c}} \\
\end{array}$ & & & \\
\hline & Other income & $\begin{array}{l}7.26 \\
(0.20)\end{array}$ & & & \\
\hline \multirow{4}{*}{$\begin{array}{c}\text { Denmark } \\
(1998-2019)\end{array}$} & Public debt & & $\begin{array}{l}21.24 \\
\left(0.00^{\mathrm{a}}\right) \\
\end{array}$ & $\begin{array}{c}4.23 \\
(0.51) \\
\end{array}$ & $\begin{array}{c}0.7 \\
(0.40) \\
\end{array}$ \\
\hline & FDI income & $\begin{array}{l}30.21 \\
\left(0.00^{a}\right) \\
\end{array}$ & & & \\
\hline & Portfol. income & $\begin{array}{l}32.84 \\
\left(0.00^{\mathrm{a}}\right) \\
\end{array}$ & & & \\
\hline & Other income & $\begin{array}{c}3.34 \\
(0.06)^{\mathrm{c}} \\
\end{array}$ & & & \\
\hline \multirow{4}{*}{$\begin{array}{c}\text { Finland } \\
(1998-2019)\end{array}$} & Public debt & & $\begin{array}{c}1.91 \\
(0.75)\end{array}$ & $\begin{array}{c}0.01 \\
(0.94)\end{array}$ & $\begin{array}{c}6.98 \\
(0.13) \\
\end{array}$ \\
\hline & FDI income & $\begin{array}{l}1.85 \\
(0.76) \\
\end{array}$ & & & \\
\hline & Portfol. income & $\begin{array}{c}7.64 \\
\left(0.00^{\mathrm{a}}\right) \\
\end{array}$ & & & \\
\hline & Other income & $\begin{array}{l}21.50 \\
\left(0.00^{\mathrm{a}}\right) \\
\end{array}$ & & & \\
\hline \multirow{4}{*}{$\begin{array}{c}\text { Sweden } \\
\text { (1998-2019) }\end{array}$} & Public debt & & $\begin{array}{c}0.41 \\
(0.51) \\
\end{array}$ & $\begin{array}{c}3.64 \\
\left(0.05^{\mathrm{b}}\right) \\
\end{array}$ & $\begin{array}{c}3.70 \\
(0.15) \\
\end{array}$ \\
\hline & FDI income & $\begin{array}{c}0.70 \\
(0.40) \\
\end{array}$ & & & \\
\hline & Portfol. income & $\begin{array}{c}0.12 \\
(0.72) \\
\end{array}$ & & & \\
\hline & Other income & $\begin{array}{c}0.12 \\
(0.93) \\
\end{array}$ & & & \\
\hline
\end{tabular}

Note: ED denotes public debt growth. Behind the country name the sample range is listed in parentheses. The numbers in the parentheses beside the Wald statistics are the P-values: a, b, c represent the 1\%, $5 \%$, and $10 \%$ significance levels, respectively. Source: calculated by the authors 
and external debt. In Denmark: direct and portfolio investment returns affect external debt. In Finland: income from other investments affects debt. The influence of external debt on the return on portfolio investments was also identified. In Sweden, there is a mutual causality between external debt and portfolio and other investment income.

Granger's causality test for increasing public debt and direct, portfolio and other investment income showed that direct and portfolio investment income, received by Norway, affects the change in public debt. In Denmark, there is a mutual causality between the level of public debt and the income of other investments, and the accumulation of public debt affects the growth of portfolio and other investment income. In Finland, a change in the public debt indicator entails a change in the income levels of direct and portfolio investments. For Sweden, mutual causality was not found between research variables.

Granger causality test conducted to identify the dependence between investment income, which was paid by countries and public debt showed: that the direct investment income affects public debt and there is a mutual causality between portfolio investment returns and debt growth in Norway. There is a mutual dependence between direct investment income and public debt and returns from portfolio and other investments affect the value of public debt in Denmark. Income from portfolio and other investments affect the public debt in Finland. The impact of public debt on portfolio investment income was identified in Sweden.

Thus, the results of the analysis prove that investment income is one of the main factors affecting the dynamics of public and external debt of Northern countries.

\section{References:}

1. Lomachynska I., Yakubovskiy S., Plets I. (2018) Dynamics of Austrian foreign direct investment and their influence on the national economy. Baltic Journal of Economic Studies, no. 4(5), pp. 167-174. DOI: https://doi.org/10.30525/2256-0 742/2018-4-5-167-174

2. Gural A., Lomachynska I. (2017) FDI and financial development as determinants of economic growth for V4 countries. Baltic Journal of Economic Studies, no. 4(4), pp. 59-64. DOI: https://doi.org/10.30525/2256-0742/2017-3-4-59-64

3. Yakubovskyi S., Lomachynska I., Hriaznova V. North American insurance markets: features and experience for Ukraine. Vysnik Odeskogo nacionalnogo universitetu. Economica - Odessa National University Herald. Economy. 2019. Vol. 24, iss. 1(74), pp. 12-17. Available at: http://www.visnyk-onu.od.ua/journal/2019 24 1/4.pdf

4. Rodionova T., Yakubovskiy S., Kyfak A. (2019) Foreign Capital Flows as Factors of Economic Growth in Bulgaria, Czech Republic, Hungary and Poland.Research in World Economy, vol. 10, no. 4, pp. 48-57. DOI: https://doi.org/10.5430/rwe.v10n4p48

5. Alstadheim R., Blandhol C. (2018) The global financial cycle, bank capital flows and monetary policy. Evidence from Norway. Norge's Bank Research. Available at: https://papers.ssrn.com/sol3/papers.cfm?abstract_id=3128250 (accessed 29 July 2020).

6. Lomachynska I., Maslennikov E., Mumladze A. (2020) Vidiemni vidsotkovi stavky yak instrument netradytsiinoi monetarnoi polityky ta yikh vplyv na ekonomiku ta finansovi rynky [Negative interest rates as an instrument of unconventional monetary policy and their impact on the economy and financial markets]. Problemy systemnoho pidkhodu $v$ ekonomitsi - Problems of systemic approach in the economy, vol. 4(78), pp. 7-15. DOI: https://doi.org/10.32782/2520-2200/2020-4-1 (in Ukrainian)

7. Eurostat (2020) General government gross debt. Available at: https://ec.europa.eu/eurostat/tgm/table.do?tab=table\&init= $1 \&$ language $=$ en \&pcode=teina230\&plugin $=1$ (accessed 27 July 2020).

8. Eurostat (2019) General government gross debt by financial instrument. Available at: https://ec.europa.eu/eurostat/statisticsexplained/index.php?title=File:General_government_gross_debt_by_financial_instrument,_2019.png (accessed 29 July 2020).

9. Eurostat (2019) General government gross debt by sector of debt holder. Available at: https://ec.europa.eu/eurostat/ statisticsexplained/index.php?title=File:General_government_gross_debt_by_sector_of_debt_holder,_2019.png (accessed 19 July 2020).

10. The World bank (2020) International debt statistics. Available at: http://datatopics. worldbank.org/debt/ids/ (accessed 19 July 2020).

11. European central bank (2019) External debt statistics. Available at: https://www.ecb.europa.eu/stats/balance_of_payments and external/external debt/html/index.en.html (accessed 19 July 2020).

12. International Monetary Fund (2020) Databases. Available at: https://www.imf.org/en/Data (accessed 19 July 2020).

\section{Список використаних джерел:}

1. Lomachynska I., Yakubovskiy S., Plets I. Dynamics of Austrian foreign direct investment and their influence on the national economy. Baltic Journal of Economic Studies. 2018. No. 4(5). P. 167-174. DOI: https://doi.org/10.30525/22560742/2018-4-5-167-174

2. Gural A., Lomachynska I. FDI and financial development as determinants of economic growth for V4 countries. Baltic Journal of Economic Studies. 2017. No. 4(4). P. 59-64. DOI: https://doi.org/10.30525/2256-0742/2017-3-4-59-64

3. Yakubovskyi S.O., Lomachynska I.A., Hriaznova V.V. North American insurance markets: features and experience for Ukraine. Вісник Одеського національного університету. Еконоліка. 2019. Том 24. Вип. 1(74). С. 12-17. URL: http://www.visnyk-onu.od.ua/journal/201924 1/4.pdf

4. Rodionova T., Yakubovskiy S., Kyfak A. Foreign Capital Flows as Factors of Economic Growth in Bulgaria, Czech Republic, Hungary and Poland. Research in World Economy. 2019. Vol. 10. No. 4. P. 48-57. DOI: https://doi.org/10.5430/rwe.v10n4p48

5. Alstadheim R., Blandhol C. The global financial cycle, bank capital flows and monetary policy. Evidence from Norway. Norge's Bank Research, 2. 2018. URL: https://papers.ssrn.com/sol3/papers.cfm?abstract_id=3128250 (дата звернення: 29.07.2020).

6. Ломачинська I.A., Масленніков Є.I., Мумладзе А.О. Від’ємні відсоткові ставки як інструмент нетрадиційної монетарної політики та їх вплив на економіку та фінансові ринки. Проблели систелного підходу в еконоліці. 2020. Випуск 4(78). С. 7-15. DOI:https://doi.org/10.32782/2520-2200/2020-4-1

7. General government gross. Eurostat. 2020. URL: https://ec.europa.eu/eurostat/tgm/table.do?tab=table\&init=1\&languag $\mathrm{e}=$ en\&pcode=teina230\&plugin=1 (дата звернення: 27.07.2020).

8. General government gross debt by financial instrument. Eurostat. 2019. URL: https://ec.europa.eu/eurostat/statisticsexplained/ index.php?title=File:General_government_gross_debt_by_financial_instrument,_2019.png (дата звернення: 29.07.2020).

9. General government gross debt by sector of debt holder. Eurostat. 2019. URL: https://ec.europa.eu/eurostat/ statisticsexplained/index.php?title=File:General government gross debt by sector of debt holder, 2019.png (дата звернення: 19.07.2020).

10. International debt statistics. The World bank. 2020. URL: http://datatopics. worldbank.org/debt/ids/ (дата звернення: 19.07.2020).

11. External debt statistics. European central bank. 2019. URL: https://www.ecb.europa.eu/stats/balance_of_payments_and_ external/external_debt/html/index.en.html (дата звернення: 19.07.2020).

12. Databases. International Monetary Fund. 2020. URL: https://www.imf.org/en/Data (дата звернення: 19.07.2020). 
Якубовський С. 0.

Ломачинська I. А.

Іванів-Дубна М. В.

Одеський національний університет імені I. I. Мечникова

ВПАИВ АОХОАІВ ВІА ІНОЗЕМНИХ ІНВЕСТИЩІЙ

НА АЕРЖААНИЙ ТА ЗОВНІШНІЙ БОРГ КРАЇН ПІВНІЧНОЇ ЕВРОПИ

\begin{abstract}
Анотація
Необхідною умовою для подальшого прискорення економічного розвитку є підвищення продуктивності в країні, що потребує покращення умов для конкуренції, залучення висококваліфікованих кадрів, а також подальший розвиток інновацій. Як правило, це пов'язано із іноземними інвестиціями, які відіграють важливу роль для будь-якої держави, втім їх вплив на економічний розвиток не завжди є позитивним. Для більшості краін доходи від прямих, портфельних та інших інвестицій впливають на накопичення державного та зовнішнього боргу. В контексті цього, дослідження присвячено аналізу динаміки, структури, особливостей державного боргу країн Північної Європи, та впливу доходів від інвестицій на державний та зовнішній борг цих країн, зокрема Норвегії, Данії, Фінляндії, Швеції. За результатами аналізу доведено, що державний борг країн Північної Європи є помірним у порівнянні з іншими країнами. Найбільшим державний борг характерний для Швеції, а найменший для Данії. Емпіричний аналіз на основі методу авто-регресії дозволив оцінити взаємозв'язок між доходами від іноземних інвестицій і рівнем державного та зовнішнього боргу для цих країн. За результатами аналізу виявлено, що доходи від прямих, портфельних, інших інвестицій країн Північної Європи впливають на борг і навпаки. Тест причинності показав, що доходи від портфельних інвестицій, отримані Норвегією, впливають на ї̈ зовнішній борг. А між зовнішнім боргом та доходами від інших інвестицій Норвегії існує взаємозалежність. У Данії зовнішній борг впливає на дохід від прямих та інших інвестицій. В Фінляндії зміна доходу від інших інвестицій спричиняе зміну рівня зовнішнього боргу. У Швеції дохід від портфельних інвестицій впливає на зовнішній борг і навпаки. В свою чергу, зовнішній борг Швеції впливає на дохідність інших інвестицій. Отже, за результатами емпіричного аналізу доведено, що, не зважаючи на відмінності у структурі національних економік та фінансових систем, а також економічної та фінансової політики уряду, інвестиційний дохід є одним з основних факторів, що впливає на динаміку державного та зовнішнього боргу всіх країн Північної Європи.

Ключові слова: інвестиційні доходи, державний борг, зовнішній борг, країни Північної Європи.
\end{abstract}

Якубовский С. А.

Ломачинская И. А.

Иванив-Дубна М. В.

Одесский национальный университет имени И. И. Мечникова

\title{
ВАИЯНИЕ АОХОАОВ ОТ ИНОСТРАННЫХ ИНВЕСТИЦИЙ НА ГОСУААРСТВЕННЫЙ И ВНЕШНИЙ АОАГ СТРАН СЕВЕРНОЙ ЕВРОПЫ
}

Резюме
Исследование посвящено анализу динамики, структуры и особенностей государственного долга стран
Северной Европы, а также влиянию доходов от инвестиций на государственный и внешний долг Норве-
гии, Дании, Финляндии, Швеции. Эмпирический анализ позволил оценить взамосвязь между доходами
от иностранных инвестиций и уровнем государственного и внешнего долга этих стран. По результатам
анализа выявлено, что доходы от прямых, портфельных и других инвестиций влияют на долг и наоборот.
Тест причинности показал, что доходы от портфельных инвестиций, полученные Норвегией, влияют на
ее внешний долг. А между внешним долгом и доходами от других инвестиций Норвегии существует вза-
имозависимость. В Дании внешний долг влияет на доход от прямых и других инвестиций. В Финляндии
изменение дохода от других инвестиций влечет за собой изменение уровня внешнего долга. В Швеции
доход от портфельных инвестиций влияет на внешний долг и наоборот. В свою очередь, внешний долг
Швеции влияет на доходность иных инвестиций. Итак, доказано, что инвестиционный доход является
одним из основных факторов, влияющих на динамику государственного и внешнего долга стран Север-
ной Европы.
Ключевые слова: иинвестиционные доходи, государственный долг, внешний долг, Страны Северной Елючев 